\title{
A müfogsorragasztó hatása a nyugalmi kevert és a kis nyálmirigyek szekréciójára, valamint a szájszárazság érzetére teljes lemezes fogpótlást viselökben
}

\author{
Demeter Tamás dr. ${ }^{1}$ - Houman Ahmad Behbahani dr. ${ }^{2}$ - Gótai Laura dr. ${ }^{1}$ \\ Károlyházy Katalin dr. ${ }^{3}$ - Kovács Alexandra dr. ${ }^{1}$. Márton Krisztina dr. ${ }^{1}$
}

Semmelweis Egyetem, Fogorvostudományi Kar, ${ }^{1}$ Propedeutikai Tanszék, ${ }^{2}$ Gyermekfogászati és Fogszabályozási Klinika, ${ }^{3}$ Fogpótlástani Klinika, Budapest

Bevezetés és célkitüzés: Célunk annak meghatározása volt, hogy a múfogsorragasztó folyamatos használata hogyan befolyásolja a nyugalmi kevert nyálszekréciót, a palatinalis és labialis kisnyálmirigy-szekréciót, illetve a szubjektív orofacialis sicca tüneteket.

Módszer: 28, felső teljes lemezes fogpótlást viselő pácienst (átlagéletkor: $70 \pm 10$ év) vizsgáltunk. A háromhetes vizsgálat során a páciensek múfogsorragasztó krémet használtak, gyártói utasítás szerint. A szubjektív orofacialis sicca tünetek értékelésére 16 kérdéses kérdőívet alkalmaztunk. A nyugalmi kevert nyálszekréció meghatározása köptetéses módszerrel, a palatinalis és a labialis szekréció mérése Periotron ${ }^{\circledR}$ eszközzel, szưrőpapír korongokkal történt a kezdeti alkalommal, majd az első, második és harmadik hét végén.

Statisztikai analizis: Az elemzéshez a következő próbákat alkalmaztuk: szubjektív adatok - $\chi^{2}$-teszt; nyálszekréciós adatok - ANOVA, Student-féle egymintás t-próba.

Eredmények: A kérdőívre adott válaszok alapján a xerostomia gyakorisága, illetve intenzitása nem változott. A vizsgálat végére szignifikánsan nőtt a nyálukat sưrúnek érző páciensek aránya ( $\mathrm{p}=0,027)$, a többi szubjektív paraméter változatlan maradt. A nyugalmi kevert szekréció értékében sem tapasztaltunk szignifikáns változást $(0$. hét: $0,37 \pm$ $0,36 \mathrm{ml} / \mathrm{min} ; 3$. hét: $0,39 \pm 0,35 \mathrm{ml} / \mathrm{min})$. A palatinalis szekréció szignifikánsan csökkent a harmadik hét végére $(0$. hét: $4,21 \pm 3,96 \mu \mathrm{l} / \mathrm{cm}^{2} / \mathrm{min} ; 3$. hét: $\left.2,21 \pm 2,30 \mu \mathrm{l} / \mathrm{cm}^{2} / \mathrm{min} ; \mathrm{p}=0,024\right)$, míg a labialis szekréció értékei nem változtak (0. hét: $3,99 \pm 3,75 \mu \mathrm{l} / \mathrm{cm}^{2} / \mathrm{min} ; 3$. hét: $2,58 \pm 3,39 \mu \mathrm{l} / \mathrm{cm}^{2} / \mathrm{min}$ ).

Következtetések: A kapott eredmények alapján a 3 hetes múfogsorragasztó-használat nem befolyásolja jelentősen sem az intraoralis, sem az extraoralis szárazsági tüneteket, így a szájszárazság érzetét sem. A palatinalis kis nyálmirigyek szekréciójának jelentős csökkenése kimutatható. Azonban, összhangban a korábban kapott eredményekkel, ez a jelenség nem befolyásolja szignifikánsan a nyugalmi kevert nyálszekréció értékét, annak ellenére, hogy a műfogsorragasztót használók megváltozott nyálkonzisztenciáról (sứrúbb nyál) számolhatnak be.

Orv Hetil. 2018; 159(40): 1637-1644.

Kulcsszavak: fogpótlás retenciója, adhezívek, nyálszekréció, kis nyálmirigyek, xerostomia

\section{Effect of a gel-type denture adhesive on unstimulated whole saliva and minor salivary gland flow rates and on subjective orofacial sicca symptoms}

Introduction and aim: To determine whether the continuous use of gel-type denture adhesives influence the unstimulated whole saliva, the palatal and labial saliva flow rates, and to assess the possible changes of subjective orofacial sicca symptoms.

Method: 28 maxillary complete denture wearing patients (average age: $70 \pm 10$ years) were investigated. A gel-type denture adhesive was administered to the patients for regular use during the 3 weeks of examination. A questionnaire of 16 questions was used to evaluate subjective orofacial sicca symptoms. Unstimulated whole saliva was determined 
by the spitting method, palatal and labial saliva flow rates were measured by the Periotron ${ }^{\circledR}$ device with filter paper discs at the initial, first, second and third weeks.

Statistical analysis: The following tests were used: subjective values $-\chi^{2}$-test; flow rates - ANOVA, paired Student's t-test.

Results: According to the questionnaire, the ratio or severity of xerostomia did not change. A significant increase in the subjective feeling of "saliva thickness" could be detected $(\mathrm{p}=0.027)$, but the other subjective parameters remained unchanged. Palatal saliva flow rates decreased significantly by week 3 (week $0: 4.21 \pm 3.96 \mu \mathrm{l} / \mathrm{cm}^{2} / \mathrm{min}$; week $\left.3: 2.21 \pm 2.30 \mu \mathrm{l} / \mathrm{cm}^{2} / \mathrm{min} ; \mathrm{p}=0.024\right)$. On the other hand, there was no significant change in the unstimulated whole saliva (week 0: $0.37 \pm 0.36 \mathrm{ml} / \mathrm{min}$; week $3: 0.39 \pm 0.35 \mathrm{ml} / \mathrm{min}$ ) and labial saliva (week $0: 3.99 \pm 3.75$ $\mu \mathrm{l} / \mathrm{cm}^{2} / \mathrm{min}$; week $3: 2.58 \pm 3.39 \mu \mathrm{l} / \mathrm{cm}^{2} / \min$ ) flow rates.

Conclusions: The regular use of denture adhesives did not influence xerostomia and the majority of subjective orofacial sicca symptoms, but may cause a subjective feeling of "increased saliva thickness" and reduce palatal minor salivary gland flow rates among complete maxillary denture wearers.

Keywords: denture retention, adhesives, salivation, minor salivary glands, xerostomia

Demeter T, Behbahani HA, Gótai L, Károlyházy K, Kovács A, Márton K. [Effect of a gel-type denture adhesive on unstimulated whole saliva and minor salivary gland flow rates and on subjective orofacial sicca symptoms]. Orv Hetil. 2018; 159(40): 1637-1644.

(Beérkezett: 2018. május 1.; elfogadva: 2018. június 1.)

\section{Rövidítések}

ANOVA $=($ analysis of variance $)$ varianciaanalízis; $\mathrm{LSZ}=$ labialis szekréció; NYKSZ = nyugalmi kevert nyálszekréció; PSZ = palatinalis szekréció

A fejlett államokban, így Magyarországon is, a fokozatos csökkenés ellenére továbbra is jelentős a teljesen fogatlan idős korú páciensek aránya (2004-ben a 65-74 éves korcsoportban $19,8 \%$ volt a fogatlanság prevalenciája) [1]. A teljes fogatlanság aránya mind Nyugat-, mind KeletKözép-Európában hasonló [2]. Ezen páciensek fogászati ellátása során a hagyományos teljes lemezes fogpótlás a mai napig megfelelő és elfogadott, jelentős hányaduknak az egyetlen terápiás lehetőséget jelenti. A fogatlan páciensek protetikai rehabilitációjáról kimutatták, hogy egyértelműen javítja az életminőséget, ugyanakkor a nem megfelelő stabilitással rendelkező teljes fogpótlások viselése negatív hatással lehet a páciensek szájüregi egészséggel kapcsolatos életminőség-mutatóira [3, 4]. Az ellátás sikeressége számos tényezőtől függhet, többek között a kezelőorvos szakértelmétől, a szájüregi körülményektől vagy a páciens együttmúködési készségétől [5]. Amellett, hogy páciensei teljes fogpótlással való ellátásakor a gyakorló fogorvosnak képességei legjavát kell nyújtania, a protézisrögzítő anyagok használata a teljes fogpótlást viselők számára jó alternatívát jelenthet. A protézisrögzítők ugyanis hatékonyan fokozzák a fogpótlások rögzítettségét, elősegítve ezáltal a komfortosabb fogsorviselést.

$\mathrm{Az}$ első protézisrögzítőre vonatkozó szabadalmat 1913-ban adták ki, majd ezt újabbak követték az 1920as és 1930-as években [6]. Ipari beszámolókból becsült adatok alapján a teljes fogpótlást viselők körülbelül 33\%-a használt protézisrögzítőt [7]. Csak az Egyesült Államokban a viselt teljes fogpótlások száma az 1991-ben regisztrált 33,6 millióról 2020-ra várhatóan 37,9 millióra fog növekedni [8].

A számos, használatukat támogató tanulmány ellenére a protézisrögzítók megítélése több klinikus számára továbbra is ellentmondásos. A fogorvos-társadalomban széleskörűen elterjedt nézet, hogy a múfogsorrögzítők használatának szükségessége a fogpótlást készítő orvos gyengébb szakmai képességeit tükrözi [9].

A protézisrögzítők a rögzítettség növekedését kizárólag a fogpótlás felszíne és a szájnyálkahártya közti adhézió fokozásával érik el. Használatuk a tanulmányok alapján kedvező szubjektív hatásokkal jár. Helyes alkalmazásuk fokozza a stabilitást és a retenciót, valamint a rágóerôt, minimalizálja a szöveti irritációkat, csökkenti a fogpótlás-korrekciók gyakoriságát és a mucosa vérellátási zavarait [10-18].

A protézisrögzítők számos összetevője - többek között a gumi, a pektin, a metil-cellulóz, a hidroxi-metilcellulóz, a karboxi-metil-cellulóz, a nátrium-cellulóz, valamint a szintetikus polimerek - mind fiziológiailag, mind mechanikailag fokozza a fogpótlás stabilitását. Emellett egyéb összetevőket is tartalmaznak, úgymint antimikrobiális szereket, adalékanyagokat, színező- és tartósítószereket. A protézisrögzítők por, gél, krém, csík vagy párna formulákban érhetők el a kereskedelmi forgalomban [19].

A retenció további fokozása érdekében számos formulához kalcium- és cinksókat adtak. A protézisrögzítők túlzott használatával járó cinkbevitel több dokumentált esetben hypocupraemiát, majd következményes neurológiai problémákat okozott, a cinktartalmú komponensek hozzáadását emiatt újabban nem javasolják [20-23]. 
Számos tanulmány a protézisrögzítőknek a fibroblastsejtkultúrákra kifejtett in vitro citotoxikus hatását mutatta ki [24-26]. Ugyanakkor a protézisrögzítók biokompatibilitását vizsgáló in vitro és in vivo tanulmányok jelenleg még meglehetősen hiányosak.

Collins és Dawes rámutatott, hogy a palatinalis szájnyálkahártya-terület a legkevésbé nyállal fedett, valamint a xerostomia (a szájszárazság szubjektív érzete) megjelenése a szájüregi nyálkahártyafelszíneken jelen lévő folyadékfilm mennyiségének függvénye [27]. Wolff és Kleinberg mindemellett azt találták, hogy a nyugalmi kevert nyálszekréció (NYKSZ) nagymértékben összefügg a palatinalis nyálfilm vastagságával, melynek elvékonyodása jellegzetes faktora a szájszárazság szubjektív érzetének [28]. Niedermeyer és Krämer vizsgálata összefüggést mutatott ki a fogpótlás retenciója és stabilitása, valamint az NYKSZ, illetve a palatinalis nyálszekréció (PSZ) között [29]. A megfelelő mennyiségű, palatinalis kis nyálmirigyek által termelt mucinosus nyálfilm jelenléte fontos, a felső teljes fogpótlás retencióját fokozó tényező lehet xerostomiában és/vagy hyposalivatióban szenvedő pácienseknél [30].

$\mathrm{Az}$ irodalomban mind ez idáig nem találtunk olyan közleményt, amely a protézisrögzítők használatának a nyálszekrécióval, valamint a szubjektív intra- és extraoralis sicca tünetek meglétével, hiányával vagy súlyosságával való összefüggését vizsgálja.

A jelen közlemény célja annak meghatározása, hogy teljes felső fogpótlást viselő páciensekben a vizsgált müfogsorragasztó három héten keresztül történő rendszeres használata hogyan befolyásolja a szájszárazság, valamint a szubjektív intra- és extraoralis sicca tünetek előfordulását, illetőleg hogyan változtatja meg a már meglévő szubjektív szárazságtünetek súlyosságát. További célja, hogy vizsgálja a protézisrögzítő háromhetes használatának az NYKSZ-re, valamint a PSZ és a labialis (LSZ) kis nyálmirigyek szekréciójára kifejtett lehetséges hatásait.

\section{Módszer}

A három hétig tartó követéses vizsgálatban huszonnyolc páciens (11 férfi, 17 nő) vett részt, átlagos életkoruk 70 \pm 10 év. Mindannyian több mint öt éve teljes lemezes fogpótlást viseltek, protézisrögzítők használata nélkül. A 28, random módon kiválasztott páciens új felső fogpótlások készíttetése végett jelentkezett a Semmelweis Egyetem Fogorvostudományi Karának Fogpótlástani Klinikáján (Budapest). Minden pácienst a fogpótláskészítés klinikai munkafázisai számára előre egyeztetett időpontokban vizsgáltuk meg, a kezelések megkezdése előtt.

Vizsgálatunkat a Semmelweis Egyetem Tudományos és Kutatásetikai Bizottságának engedélyével (TUKEBengedélyszám: 104/2003) és az embereken végzett vizsgálatokra vonatkozó 23/2002-es EüM-rendelet, valamint az Orvosi Világszövetség által létrehozott helsinki
1. táblázat $\mid$ A szubjektív orofacialis és következményes extraoralis szárazság tünetek értékelésére szolgáló kérdőív

\begin{tabular}{|c|c|}
\hline $\begin{array}{l}\text { 1. Gyakran érzi száraznak } \\
\text { a száját? }\end{array}$ & 2. Vannak-e nyelési nehézségei? \\
\hline $\begin{array}{l}\text { 3. Gyakran ég vagy bizsereg } \\
\text { a nyelve? }\end{array}$ & $\begin{array}{l}\text { 4. Lelassul, akadozik a beszéde, } \\
\text { ha relatíve hosszú ideig beszél? }\end{array}$ \\
\hline 5. Van ízérzési problémája? & $\begin{array}{l}\text { 6. Érzése szerint nincs elég } \\
\text { nyál a szájában? }\end{array}$ \\
\hline 7. Gyakran súrú a nyála? & 8. Könnyen szuvasodik a foga? \\
\hline 9. Ki szokott száradni az orra? & 10. Gyakran száraz a szeme? \\
\hline $\begin{array}{l}\text { 11. Szeme gyakran viszket, } \\
\text { ég, gyakran érez benne idegen } \\
\text { testet? }\end{array}$ & 12. Érzékeny a fényre? \\
\hline $\begin{array}{l}\text { 13. Gyakran érzi száraznak } \\
\text { a bőrét? }\end{array}$ & $\begin{array}{l}\text { 14. Szenved hüvelyi } \\
\text { szárazságban? }\end{array}$ \\
\hline $\begin{array}{l}\text { 15. Szenved-e hüvelyi égésben, } \\
\text { visszatérő gombás fertőzésben? }\end{array}$ & $\begin{array}{l}\text { 16. Gyakran érzi fáradtnak } \\
\text { magát? }\end{array}$ \\
\hline
\end{tabular}

nyilatkozat figyelembevételével végeztük. A vizsgálatok elkezdése előtt minden részt vevő páciens beleegyező nyilatkozatot írt alá.

\section{A szubjektiv orofacialis és köpetkezményes extraoralis sicca tünetek vizsgálata}

Részletes általános, illetve fogászati anamnézis felvételét követően a páciensek külön erre a vizsgálatra összeállított kérdőívet töltöttek ki annak érdekében, hogy segítségével meghatározzuk a szubjektív orofacialis és következményes extraoralis sicca tünetek meglétét, hiányát, valamint súlyosságát. A páciensek által kitöltött kérdőívben szereplő kérdések az 1. táblázatban találhatók. A kérdésekre adott lehetséges válaszok négyfokozatú skálán helyezkednek el (nem - 0, enyhe - 1, közepes - 2, erős - 3), hogy az egyes szubjektív tünetek súlyossága megítélhető legyen.

\section{Klinikai vizsgálatok (a nyálszekréció mérése)}

Az NYKSZ meghatározása a kérdőív kitöltését követően köptetéses módszerrel történt, a Sreebny által leírt módszer alapján. A páciensek ülő helyzetben nyálukat 5 percen keresztül egy előre lemért tömegű edénybe ürítették, miközben tartózkodniuk kellett a nyeléstől, illetve a jelentősebb mozgástól. A mérést megelőző két órában a páciensek nem fogyaszthattak ételt vagy italt. Az edények tömege üresen, illetve a gyújtés után elektromos mérleggel (Acculab VI-200, Sartorius, Göttingen, Németország) lemérésre került $[31,32]$.

A nyál sürüségét $1 \mathrm{~g} / \mathrm{cm}^{3}$-nek tekintve, a mérlegen grammokban megjelenített értékeket milliliterben fejeztük ki, a nyálszekréciós rátát pedig $\mathrm{ml} / \mathrm{min}$ értékben adtuk meg. 0,1 ml/min-nél alacsonyabb NYKSZ esetén hyposalivatióról beszélhetünk [32, 33]. 
A PSZ mérése a felső fogatlan állcsontgerincen, a felső második nagyőrlők helyétől körülbelül $15 \mathrm{~mm}$-rel a középvonal felé lévő területre helyezett, $8 \mathrm{~mm}$ átmérőjü szưrőpapír korongokkal (Oraflow Inc., Amityville, NY, Amerikai Egyesült Államok) történt, a kemény szájpad két oldalán (1/a ábra). Az LSZ mérése során a szürőpapír korongokat az alsó ajak középvonalára, a kifordított nyálkahártya felületére helyeztük. A kisnyálmirigy-szekréciós mérések a terület gézlappal történő óvatos szárítását követően, relatív izolálásban (buccalis áthajlásba helyezett vattarolnival, a parotis szekrétumának kontrollálására) történtek, és 30 másodpercig tartottak. Ezt követte a szűrőpapír korongokkal felitatott nyálmennyiség elektromos vezetőképességének mérése a Periotron ${ }^{\circledR}$ 8000 (Oraflow Inc.) készülékkel ( $1 / b$ ábra). A mért értékeket a készülék kalibrációs táblázatának segítségével kalibráltuk, így a kisnyálmirigy-szekréció értékeit $\mu \mathrm{l} /$ $\mathrm{cm}^{2} /$ min egységekben lehetett kifejezni [30].

\section{A protézisrögzitôk használata}

Az első (kontroll-) vizsgálat során a páciensek tájékoztatást és instrukciókat kaptak a vizsgált múfogsorragasztó (Blend-a-Dent Extra Stark Neutral, Procter \& Gamble Magyarország Kkt., Budapest) elkövetkező 3 héten át történő rendszeres használatáról. A gyártói utasításoknak megfelelően három, egyenként körülbelül 2-3 cm hosszúságú csíkot kell applikálni a fogpótlások palatinalis nyálkahártyával érintkező, előzetesen megtisztított, majd leszárított felszínére, majd a fogpótlásokat pár másodpercig tartó határozott nyomással kell behelyezni $(\mathrm{l} / \mathrm{c}$ ábra). A müfogsor behelyezését követően néhány percig nem szabad enni vagy inni. Minden páciens megkapta és tudomásul vette a protézisrögzítők helyes használatának instrukcióit. A betegeket a kontrollvizsgálatot követően háromszor vizsgáltuk; a vizsgálatok időpontjai három héten át, hétről hétre mindig ugyanazon a napon és ugyanabban az időpontban történtek. Az első (kontroll-) vizsgálat során a következő termékekkel láttuk el a pácienseket: Blend-a-Dent Extra Stark Neutral (Procter \& Gamble Magyarország Kkt.) gél típusú protézisrögzítő, Blend-a-Dent 2-Phasen Ultra protézistisztító tabletták, valamint Oral-B 3D White fogkefe (a fogpótlások mindennapi tisztán tartására).

\section{Statisztikai analizis}

Minden adatot átlag \pm szórás formátumban fejeztünk ki. A statisztikai kiértékelést az SPSS for Windows szoftver 15.0-ás verziójával (SPSS Inc., Chicago, MI, Amerikai
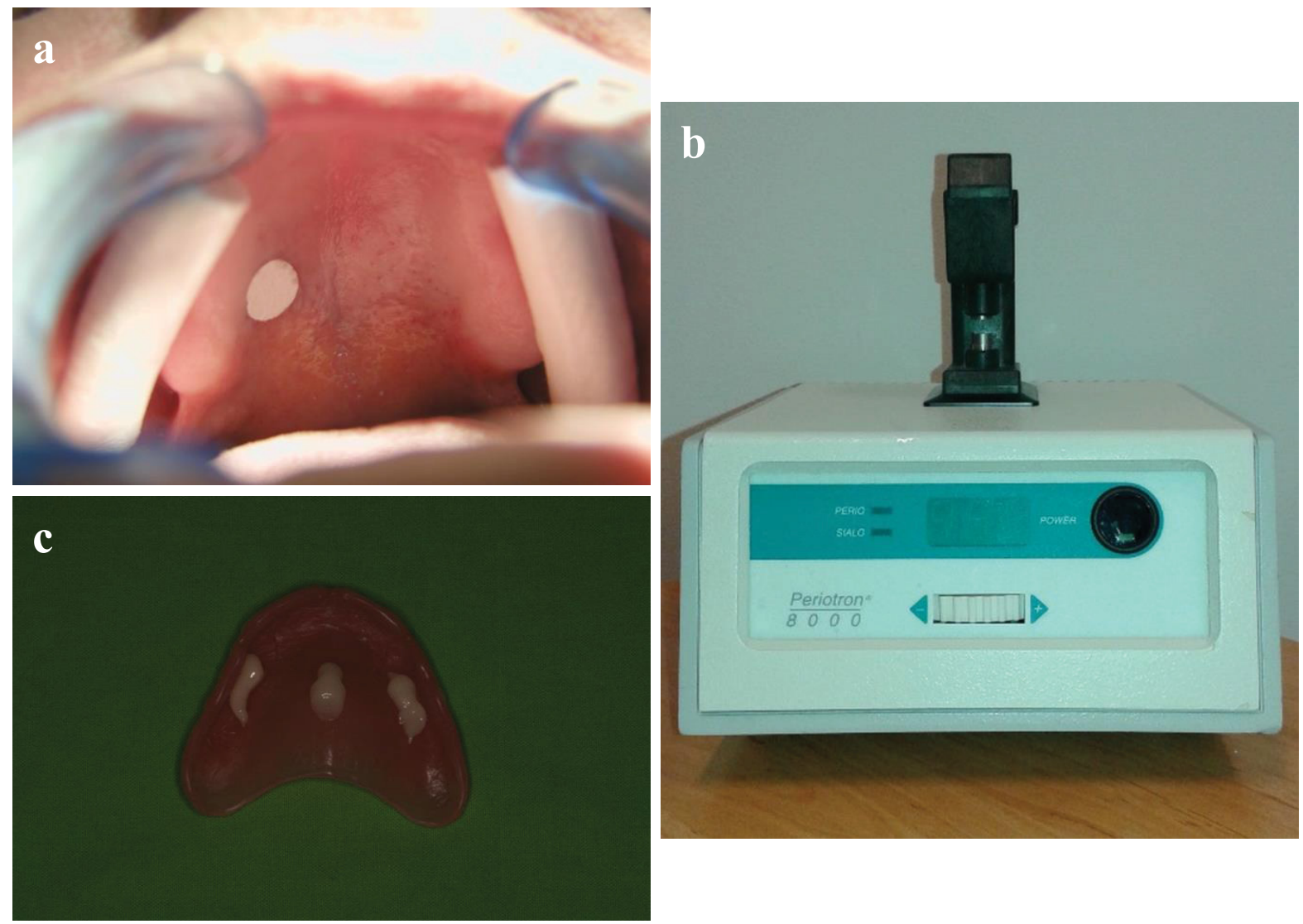

1. ábra

a) Szűrőpapír korongok (Saliva paper®, Oraflow Inc., Amityville, NY, Amerikai Egyesült Államok) a kemény szájpad jobb oldalára helyezve, a palatinalis kisnyálmirigy-szekréció mérésére. b) Periotron ${ }^{\circledR} 8000$ (Oraflow Inc.) készülék. c) A vizsgált műfogsorragasztó applikálása a felső teljes lemezes fogpótlás mucosalis felszínére, a gyártó utasítása szerint 
Egyesült Államok) végeztük, a szubjektív tüneteknél a $\chi^{2}$-próba, a heti nyálszekréciós értékek változásának elemzésekor az ANOVA, valamint az egymintás t-próba alkalmazásával. A statisztikai szignifikancia szintje: $\mathrm{p}<0,05$.

\section{Eredmények}

A szubjektív siccatünetek változásai

A kérdőívre hétről hétre adott válaszokat a 2. és 3. ábra összegzi. Az eredmények alapján nem tapasztaltunk

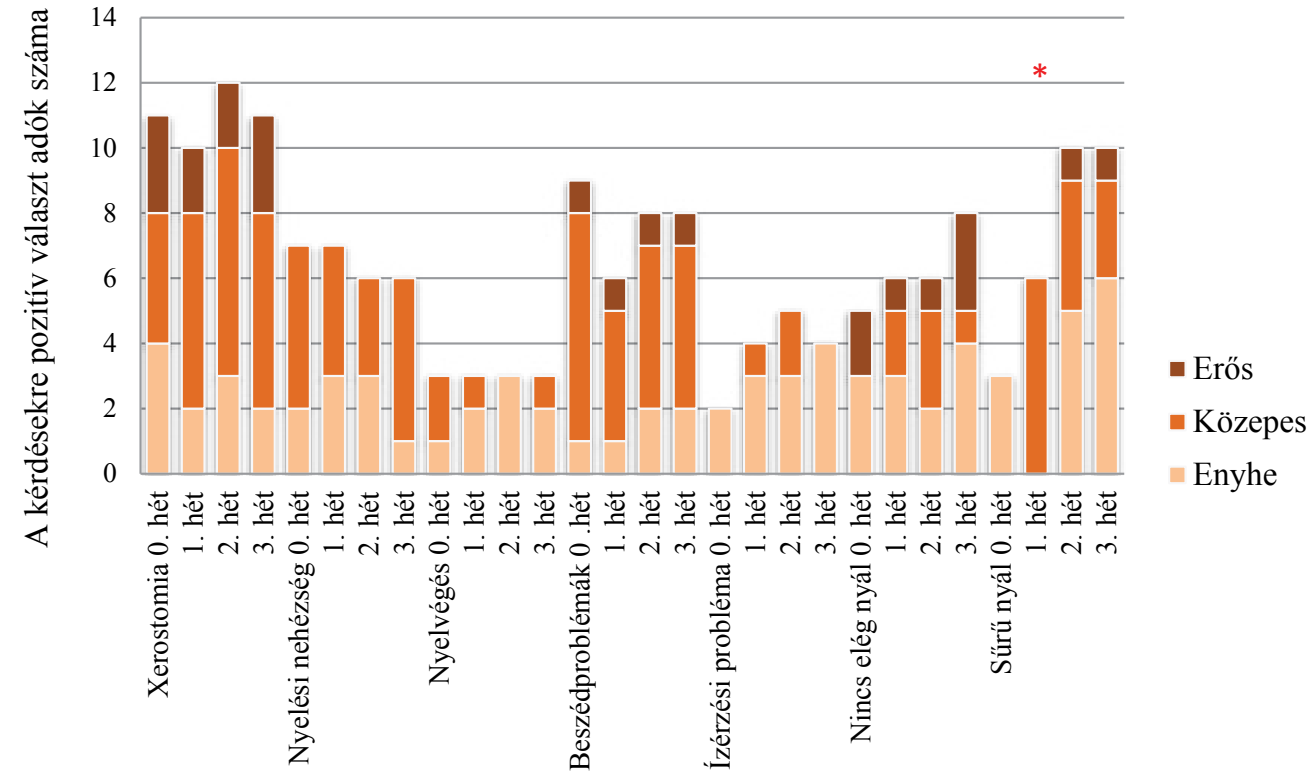

Kérdőívben szereplö tünetek

2. ábra

Az intraoralis szárazság tüneteinek változása a vizsgált teljes lemezes fogpótlást viselőkben $(\mathrm{n}=28)$ a protézisrögzítő használatának három hete során. Az adott tünetre, az adott héten pozitív választ adó páciensek számát az y tengely mutatja. A „Gyakran érzi sürúnek a nyálát?” kérdésre adott „Igen” válaszok száma szignifikánsan magasabb volt a 3 . héten $(\mathrm{n}=10)$, összehasonlítva a kiindulási értékkel $(\mathrm{n}=3)$

* $=$ p $<0,05$ a $\chi^{2}$-próba alapján

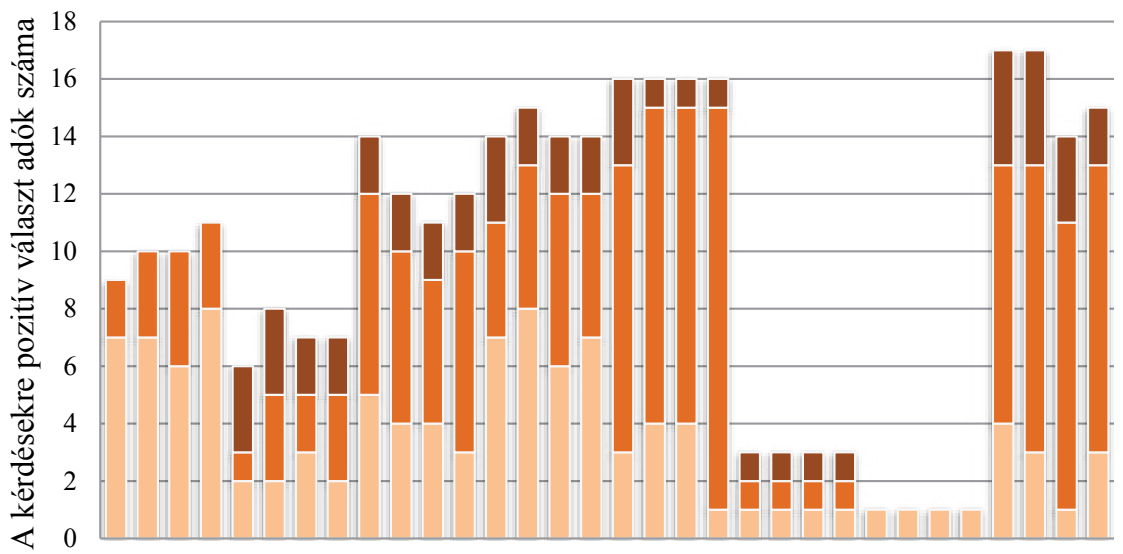

- Erös

- Közepes

Enyhe

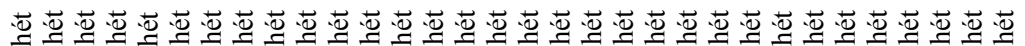

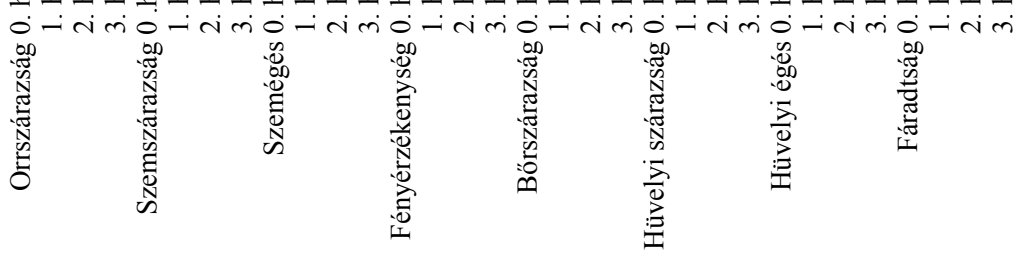

Kérdőívben szereplő tünetek

3. ábra $\quad$ Az extraoralis szárazság tüneteinek változása a vizsgált teljes lemezes fogpótlást viselőkben $(\mathrm{n}=28)$ a protézisrögzítő használatának három hete során. Az adott tünetre, az adott héten pozitív választ adó páciensek számát az y tengely mutatja. A tünetek megjelenésében és intenzitásában nem tapasztaltunk szignifikáns változást a három hét alatt 
szignifikáns változást a szájszárazság, a nyelési nehézség, a nyelvégés, a nehezített beszéd, valamint az ízérzési nehézség tüneteinek megjelenésénél vagy intenzitásánál. Ugyanakkor a sűrü nyál szubjektív érzete a kiindulási ( 0 . hét) értékhez képest jelentősen, mintegy két és félszeresére nőtt az 1 . hétre (2. ábra). Ez az érték a kiindulásinak a 3,3-szorosára növekedett a 3 . hétre $(\mathrm{p}=0.027$, a $\chi^{2}$-próba alapján). A csökkent nyálmennyiség érzetét produkáló páciensek száma hétről hétre emelkedett, ugyanakkor ez a változás nem bizonyult szignifikánsnak. Az extraoralis szárazság tünetei közül (3. ábra) az orrszárazság esetében tapasztaltunk növekedést, amely azonban nem bizonyult szignifikánsnak. A fáradtság, a száraz bőr, a fényérzékenység, valamint a nőgyógyászati és szemészeti szárazsági tünetek nem változtak a három hét során.

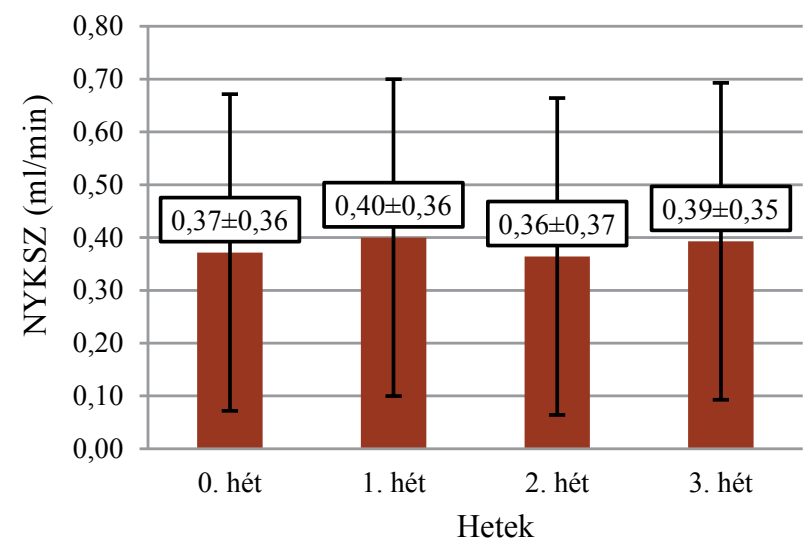

A nyugalmi kevert nyálszekréció változása a vizsgált teljes lemezes fogpótlást viselőkben $(\mathrm{n}=28)$ a protézisrögzítő használatának három hete során. Az y tengely az adott héten a köptetéses módszerrel mért nyálszekréciós értékeket jelöli $(\mathrm{ml} / \mathrm{min})$. Nem tapasztaltunk szignifikáns változást a Student-féle egymintás tpróba alapján

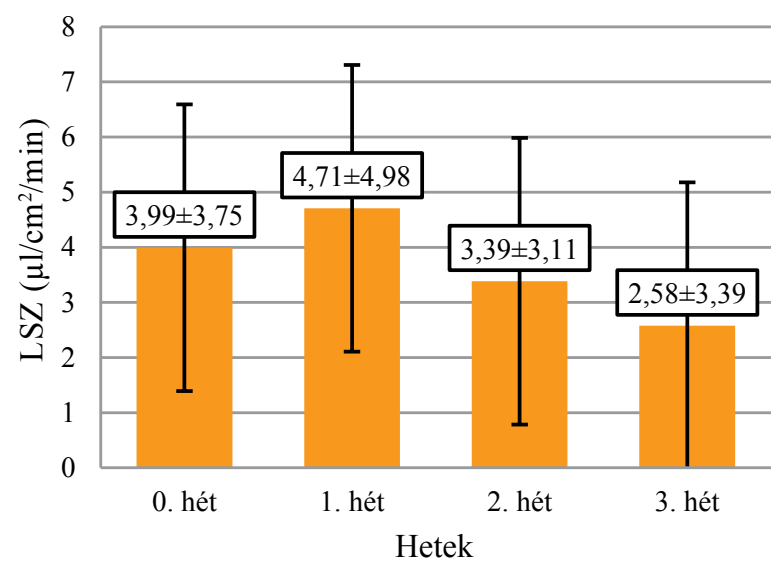

5. ábra Az alsó ajak kisnyálmirigy-szekréciójának változása a vizsgált tel-
jes lemezes fogpótlást viselőkben $(\mathrm{n}=28)$ a protézisrögzítő
használatának három hete során. Az y tengely az adott héten a
Periotron ${ }^{\circledR}$ eszközzel mért nyálszekréciós értékeket jelöli ( $\mu \mathrm{l} /$
$\left.\mathrm{cm}^{2} / \mathrm{min}\right)$. A szekréció csökkenése nem volt szignifikáns az
ANOVA-teszt alapján
ANOVA = varianciaanalízis

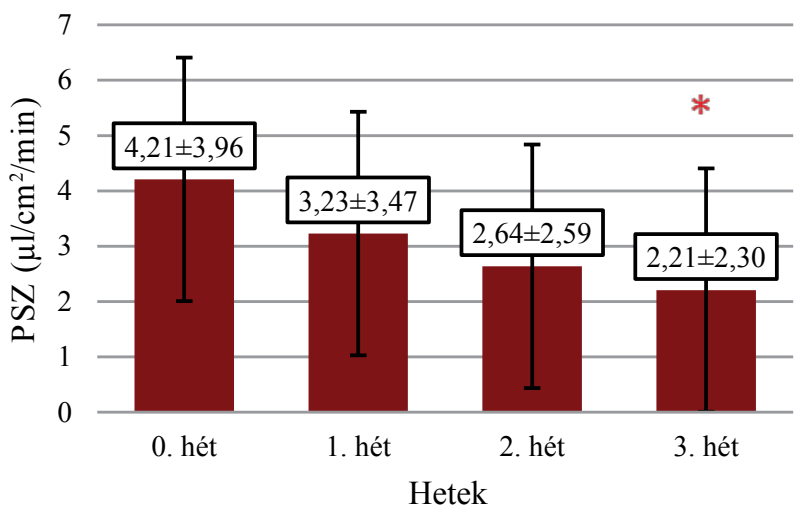

6. ábra A szájpadi kis nyálmirigyek szekréciójának változása a vizsgált
teljes lemezes fogpótlást viselókben $(\mathrm{n}=28)$ a protézisrögzítő
használatának három hete során. Az y tengely az adott héten a
Periotron@ eszközzel mért nyálszekréciós értékeket jelöli $(\mu \mathrm{l} /$
$\left.\mathrm{cm}^{2} / \mathrm{min}\right)$. A szekréció folyamatosan csökkent, és ez a csökkenés
a harmadik hét végére szignifikánssá vált
* $=\mathrm{p}<0,05$ az ANOVA-teszt alapján; ANOVA = varianciaana-
lízis

\section{A nyálszekréciós értékek változásai}

Az NYKSZ átlagolt értékei az 4. ábrán láthatók. A vizsgálat három hete során nem tapasztaltunk szignifikáns változást ebben a paraméterben $(\mathrm{p}=0,824)$.

Az LSZ értéke (5. ábra) a kiindulási 3,99 $\mu \mathrm{l} / \mathrm{cm}^{2} / \mathrm{min}$ értékről (kontroll) a harmadik hétre $2,58 \mu \mathrm{l} / \mathrm{cm}^{2} / \mathrm{min}$ értékre csökkent, de ez a csökkenés nem volt szignifikáns $(\mathrm{p}=0,145)$.

A PSZ mértékét (6. ábra) a kiindulási alkalommal $4,21 \mu \mathrm{l} / \mathrm{cm}^{2} /$ min-nek mértük, ez folyamatosan csökkent hétról hétre, a 3 . héten mért $2,21 \mu \mathrm{l} / \mathrm{cm}^{2} /$ min értékre. Ez a csökkenés ugyanakkor szignifikánsnak bizonyult $(\mathrm{p}=0,024)$.

\section{Megbeszélés}

Jelen vizsgálatunk célja a protézisrögzítők lehetséges hatásának vizsgálata volt a szubjektív oralis, illetve következményes extraoralis sicca tünetek megjelenésére és intenzitására, valamint a nagy és kis nyálmirigyek nyálszekréciójára. A kérdőívre adott válaszok alapján (2. és 3. ábra) felmérhetők a páciensek szubjektív tüneteiben bekövetkezett változások. Figyelembe véve a vizsgált populáció átlagéletkorát (70 év), a szubjektív tünetek, valamint a nyálszekréciós értékek tekintetében, előzetes várakozásainknak megfelelően megfigyelhető volt a xerostomia incidenciájának magasabb, valamint a nyáltermelés mértékének alacsonyabb értéke, többek között az öregedéssel összefüggő fiziológiai változások következményeként. A vizsgált páciensek egyharmada szenvedett xerostomiában, ami egyezést mutat egy szintén Magyarországon végzett xerostomiavizsgálat eredményeivel [34]. Mindazonáltal a kapott eredmények tükrében a protézisrögzítők rendszeres napi használata nem befo- 
lyásolta lényegesen ennek a tünetnek sem az incidenciáját, sem az intenzitását a vizsgált teljes fogpótlást viselőkben.

A protézisrögzítők használatának javaslatával, a használat következményeként a viselt fogpótlások általánosan nagyobb stabilitását, viselőinek nagyobb magabiztosságát, és társadalmi beilleszkedésük könnyebbé válását várjuk. A protézisrögzítők a maximális rágóerő, illetve a fogsor elmozdításához szükséges rágóerő értékének növelésében hatékonyabbnak bizonyultak, mint a homokfúvás vagy a fogpótlás nyálkahártya felőli felszínének egyéb felületkezelési eljárásai $[16,35,36]$. Vizsgálatunkban a protézisrögzítők rendszeres használata során a nyelési nehézség, valamint a nehezített beszéd tüneteinek enyhe csökkenését tapasztaltuk, ez azonban nem volt szignifikáns. Ez a csökkenés magyarázható lehet a felső fogpótlások retenciójának és stabilitásának a fogsorrögzítő által előidézett növekedésével, ám esetenként a régi fogpótlás nem megfelelő stabilitását nem tudta érdemben javítani a protézisrögzítő használata.

A páciensek többsége a harmadik hét végére a nyál viszkozitásának növekedéséről számolt be (sűrű nyál érzete), valamint tapasztalták a nyálmennyiség enyhe csökkenését is (2. ábra). A kérdőívre adott válaszok alapján a „sưrü nyál” tüneteit mutató páciensek száma a kétszeresére nőtt 1 hét után a kiinduláskor regisztrált értékhez képest.

Ennek oka lehet, hogy a ragasztó használata a nyál viszkozitásában, konzisztenciájában okozhatott változást, de ki kell emelnünk azt is, hogy a protézisrögzítő rendszeres használata a PSZ szignifikáns csökkenését eredményezte (6. ábra).

Az LSZ értékének változása az 5. ábrán látható. Mind a PSZ, mind az LSZ értékeinek csökkenése magyarázható azzal, hogy a protézisrögzítő rendszeres használata a viselt fogpótlások stabilizálásával, így mobilitásuk csökkenésével jár. A fogpótlás mobilitása nyálszekréciót stimuláló faktornak számít, így stabilitásuk növekedése a nyálelválasztás csökkenését vonhatja maga után. Emellett a múfogsorragasztók a palatinalis kisnyálmirigyek szájadékainak obstrukcióját okozhatják, ez pedig szintén szekréciócsökkenést idézhet elő.

Érdekes ugyanakkor, hogy az NYKSZ értéke nem változott szignifikánsan $(\mathrm{p}=0,824)$, így a nyál sűrüségének növekedése a kis nyálmirigyek csökkent szekréciójának következménye lehet, függetlenül attól, hogy a betegek nem érezték száraznak a szájukat. Ennek magyarázata lehet, hogy a palatinalis szekréció ilyen mértékű csökkenése nem okozza a palatinalis nyálfilm elvékonyodását, amely a szájszárazság egyik kulcsfaktora [28, 30].

A PSZ értékének szignifikáns változását $(\mathrm{p}=0,024)$ összehasonlítva az NYKSZ értékének nem szignifikáns változásával ( $\mathrm{p}=0,824)$, felmerülhet annak lehetősége, hogy a múfogsorragasztó használata nagyobb hatással van a palatinalis kis nyálmirigyek elválasztására, mint a nagy nyálmirigyek termelésére. A palatinalis szekréció vizsgálatunk során mért csökkenésének közvetlen oka le- het a kis nyálmirigyek atrophiája is, a szekréciócsökkenés pedig befolyással lehet a szájpadi nyálkahártya Candidakolonizációjára teljes lemezes fogpótlást viselőknél. Ezeket a feltételezéseket munkacsoportunk tervezett, jövőbeli kutatásaiban szeretné vizsgálni.

\section{Következtetések}

A kapott eredmények alapján megállapítható, hogy 3 hetes múfogsorragasztó-használat nem befolyásolja jelentősen sem az intraoralis, sem az extraoralis szárazsági tüneteket, így önmagában a szájszárazság érzetét sem. A palatinalis kis nyálmirigyek szekréciójának jelentős csökkenése kimutatható. Azonban, összhangban a korábban kapott eredményekkel, ez a jelenség nem befolyásolja szignifikánsan a nyugalmi kevert nyálszekréció értékét, annak ellenére, hogy a múfogsorragasztót használók megváltozott nyálkonzisztenciáról (sứrübb nyál) számolhatnak be.

Anyagi támogatás: A kutatómunka, valamint a közlemény megírása során a szerzők anyagi támogatásban nem részesültek.

Szerzői munkamegosztás: D. T.: Irodalomkutatás, a vizsgálat megtervezése, adatgyújtés, adatfeldolgozás, ábrák szerkesztése, a kézirat elkészítése. H. A. B.: Adatgyújtés, adatfeldolgozás, a kézirat elkészítése. G. L., K. K.: Adatgyüjtés. K. A.: Adatgyüjtés, adatfeldolgozás. M. K.: A vizsgálat megtervezése, irodalomkutatás, adatfeldolgozás, a kézirat elkészítése. A kézirat végleges változatát valamennyi szerző elolvasta és jóváhagyta.

Érdekeltségek: A szerzőknek nincsenek érdekeltségeik.

\section{Irodalom}

[1] Madléna M, Hermann P, Jáhn M, et al. Caries prevalence and tooth loss in Hungarian adult population: results of a national survey. BMC Public Health 2008; 8: 364.

[2] Marada G, Nagy Á, Sebestyén A, et al. Reimbursement of public dental care in Germany, the United Kingdom, Hungary and Poland. [A fogászati ellátás finanszírozása Németországban, az Egyesült Királyságban, Magyarországon és Lengyelországban.] Orv Hetil. 2016; 157: 547-553. [Hungarian]

[3] Veyrune JL, Tubert-Jeannin S, Dutheil C, et al. Impact of new prostheses on the oral health related quality of life of edentulous patients. Gerodontology 2005; 22: 3-9.

[4] Nagy J, Novák P, Buzás K, et al. The effect of smoking on the quality of life enhancement following prosthetic rehabilitation in head and neck cancer patients who underwent surgical treatment. [A dohányzás hatása a fej-nyak régió daganata miatt sebészi terápiában részesült betegek protetikai rehabilitációt követő életminőség-javulására.] Orv Hetil. 2017; 158: 172-177. [Hungarian]

[5] Ramstad T, Norheim PW, Eckersberg T. The reliability of clinical evaluation of some characteristics in complete prosthetics. J Oral Rehabil. 1980; 7: 11-19.

[6] Yankell SL. Overview of research and literature on denture adhe sives. Compend Contin Educ Dent. 1984; (Suppl 4): S18-S21. 
[7] Coates AJ. Usage of denture adhesives. J Dent. 2000; 28: 137140.

[8] Douglass CW, Shih A, Ostry L. Will there be a need for complete dentures in the United States in 2020? J Prosthet Dent. 2002; 87: 5-8.

[9] Grasso JE. Denture adhesives: Changing attitudes. J Am Dent Assoc. 1996; 127: 90-96.

[10] Chew CL, Boone ME, Swartz ML, et al. Denture adhesives: their effects on denture retention and stability. J Dent. 1985; 13: 152-159.

[11] Coates AJ. Denture adhesives: a review. Aust Prosthodont J. 1995; 9: 27-31

[12] Fujimori T, Hirano S, Hayakawa I. Effects of a denture adhesive on masticatory functions for complete denture wearers - consideration for the condition of denture-bearing tissues. J Med Dent Sci. 2002; 49: 151-156.

[13] Grasso JE, Rendell J, Gay T. Effect of denture adhesive on the retention and stability of maxillary dentures. J Prosthet Dent. 1994; 72: 399-405.

[14] Koppang R, Berg E, Dahm S, et al. A method for testing denture adhesives. J Prosthet Dent. 1995; 73: 486-491.

[15] Özcan M, Kulak Y, De Baat C, et al. The effect of a new denture adhesive on bite force until denture dislodgement. J Prosthodont. 2005; 14: 122-126.

[16] Psillakis JJ, Wright RF, Grbic JT, et al. In practice evaluation of a denture adhesive using a gnathometer. J Prosthodont. 2004; 13: 244-250

[17] Ghani F, Picton DC. Some clinical investigations on retention forces of maxillary complete dentures with the use of denture fixatives. J Oral Rehabil. 1994; 21: 631-640.

[18] Ghani F, Likeman PR, Picton DC. An investigation into the effect of denture fixatives in increasing incisal biting forces with maxillary complete dentures. Eur J Prosthodont Restor Dent. 1995; 3: 193-197.

[19] DeVengencie J, Ng MC, Ford P, et al. In vitro evaluation of denture adhesives: possible efficacy of complex carbohydrates. Int J Prosthodont. 1997; 10: 61-72.

[20] Lasater M. Zinc toxicity because of denture adhesive. J Neurosci Nurs. 2017; 49: 23-24.

[21] Doherty K, Connor M, Cruickshank R. Zinc-containing denture adhesive: a potential source of excess zinc resulting in copper deficiency myelopathy. Br Dent J. 2011; 210: 523-525.

[22] Tezvergil-Mutluay A, Carvalho RM, Pashley DH. Hyperzincemia from ingestion of denture adhesives. J Prosthet Dent. 2010; 103: $380-383$.
[23] Nations SP, Boyer PJ, Love LA, et al. Denture cream: an unusual source of excess zinc, leading to hypocupremia and neurologic disease. Neurology 2008; 71: 639-643.

[24] de Gomes PS, Figueiral MH, Fernandes MH, et al. Cytotoxicity of denture adhesives. Clin Oral Investig. 2011; 15: 885-893.

[25] Al RH, Dahl JE, Morisbak E, et al. Irritation and cytotoxic potential of denture adhesives. Gerodontology 2005; 22: 177-183.

[26] Ekstrand K, Hensten-Pettersen A, Kullmann A. Denture adhesives: Cytotoxicity, microbial contamination, and formaldehyde content. J Prosthet Dent. 1993; 69: 314-317.

[27] Collins LM, Dawes C. The surface area of the adult human mouth and thickness of the salivary film covering the teeth and oral mucosa. J Dent Res. 1987; 66: 1300-1302.

[28] Wolff M, Kleinberg I. Oral mucosal wetness in hypo- and normosalivators. Arch Oral Biol. 1998; 43: 455-462.

[29] Niedermeier WH, Krämer R. Salivary secretion and denture retention. J Prosthet Dent. 1992; 67: 211-216.

[30] Márton K, Boros I, Fejérdy P, et al. Evaluation of unstimulated flow rates of whole and palatal saliva in healthy patients wearing complete dentures and in patients with Sjogren's syndrome. J Prosthet Dent. 2004; 91: 577-581.

[31] Sreebny LM. Recognition and treatment of salivary induced conditions. Int Dent J. 1989; 39: 197-204.

[32] Sreebny LM. Saliva in health and disease: an appraisal and update. Int Dent J. 2000; 50: 140-161.

[33] Navazesh M, Kumar SK. Measuring salivary flow: challenges and opportunities. J Am Dent Assoc. 2008; 139(Suppl): 35S-40S.

[34] Márton K, Madléna M, Bánóczy J, et al. Unstimulated whole saliva flow rate in relation to sicca symptoms in Hungary. Oral Dis. 2008 ; 14: 472-477.

[35] de Baat C, van't Hof M, van Zeghbroeck L, et al. An international multicenter study on the effectiveness of a denture adhesive in maxillary dentures using disposable gnathometers. Clin Oral Investig. 2007; 11: 237-243.

[36] Sipahi C, Beyzadeoglu M, Demirtas S, et al. Effect of different mucosal and acrylic resin surface treatments in a denture retention model for patients with radiotherapy-induced xerostomia. Int J Prosthodont. 2007; 20: 405-408.

(Demeter Tamás dr., Budapest, Szentkirályi utca 47., 1085 e-mail: demeter.tamas@dent.semmelweis-univ.hu)

\section{„Omnis habet sua dona dies." (Martialis) (Minden napnak megvan a maga ajándéka.)}

A cikk a Creative Commons Attribution-NonCommercial 4.0 International License (https://creativecommons.org/licenses/by-nc/4.0) feltételei szerint publikált Open Access közlemény, melynek szellemében a cikk nem kereskedelmi célból bármilyen médiumban szabadon felhasználható, megosztható és újraközölhető, feltéve, hogy az eredeti szerző és a közlés helye, illetve a CC License linkje és az esetlegesen végrehajtott módosítások feltüntetésre kerülnek. 